\title{
A Quantum-Chemical Model of the Inhibition HIV-1 Intergrase Action by Iodine Complex Compounds and Lithium Halogenides
}

\section{Gulnara A Yuldasheva ${ }^{1 *}$, Radka Argirova ${ }^{2}$ and Aleksandr I llin ${ }^{3}$}

${ }^{1}$ Scientific Centre for Anti-Infectious Drugs, Kazakhstan

${ }^{2}$ Clinical Laboratory Tokuda Hospital Sofia, Bulgaria

\begin{abstract}
The water-nucleotide AGA triplet - $\mathrm{LiCl}(\mathrm{I})-\mathrm{I}_{2}-\alpha$-dextrin-peptide system was investigated using UV spectroscopy. The good agreement between the experimental UV-frequencies of the system with the theoretical frequencies for $\mathrm{LiCl}(\mathrm{I})-\mathrm{I}_{2}-\boldsymbol{\alpha}$-dextrin-nucleotide complexes indicates that when interacting with $\mathrm{LiCl}(\mathrm{I})-\mathrm{I}_{2}-\boldsymbol{\alpha}$-dextrin complexes AGA triplet nucleotides displace peptide and form a new complex with iodine and lithium halogenides.
\end{abstract}

Using the quantum-chemical DFT is was shown that the $\mathrm{LiCl}(\mathrm{I})-\mathrm{I}_{2}-\alpha$-dextrin-nucleotide complexes inhibit the activity of the catalytic site of integrase inside the PIC. They disrupt the conditions ensuring the occurrence of catalytical cleavage of the phosphoester bond in the phosphate group of the viral DNA by the active catalytic site of integrase as they form a nucleoprotein complex consisting of the nucleotides of the viral DNA, $\mathrm{LiCl}(\mathrm{I}) \mathrm{I}_{2}-\boldsymbol{\alpha}$-dextrin complexes and active components of the catalytic site of integrase. In these complexes magnesium ions are coordinated by the carbonyl oxygen atom of thymine rather than by the oxygen atoms of the phosphate group.

The effect of antiviral action of $\mathrm{LiCl}(\mathrm{I})-\mathrm{I}_{2}-\alpha$-dextrin-peptide complexes against $\mathrm{HIV}-1$ has been established on a line of lymphoblastoid human cells MT-2. The mechanism of anti-HIV action of $\mathrm{LiCl}(\mathrm{I})-\mathrm{I}_{2}-\boldsymbol{\alpha}$-dextrin-peptide complexes has been suggested.

Keywords:HIV-1 integrase; DFT-method; Molecular iodine complex

\section{Introduction}

HIV integrase inhibitors have a high therapeutic effect [1] for two reasons. First, integrase is one of the key participants in the virus replication cycle [2]. Second, integrase has no cellular equivalent and, hence, the suppression of its activity should not disturb normal cellular metabolism processes [3].

It is typical for such family of enzymes as HIV integrase to form very stable complexes with the DNA of a virus.

For integrase to be integrated it needs to bind both virus and cell DNA molecules at the same time. The integration proceeds in two stages and begins in the cytoplasm of HIV-infected cells where, upon completion of the reverse transcription of the virus DNA genome, integrase binds the virus DNA copy producing what is called the preintegration complex (PIC) which can be isolated from HIV-infected cells [4].

In the paper the authors compare the inhibiting activity of a series of antiretroviral agents in respect to the HIV-1 integrase and the in vitro-isolated PIC. The results of the study show that inhibitors active in respect to the integrase may not be active towards the PIC. The capability to inactivate the PIC was shown by three antiretroviral agents only [5].

Well-known are quite a number of iodine-polymer complexes that possess a broad spectrum of antimicrobic and antiviral action including human immunodeficiency virus (HIV).

Among them is Armenicum which is a drug to treat HIV infection [6-8]. Recently a new anti-infective drug with anti-HIV action has been patented (AID) [9].

The distinctive feature of those drugs is that their active substance includes not only the iodine-containing polymeric complex, but also potassium and lithium halogenides.
Under the influence of molecular iodine the whole of known microbial flora is killed, as it has antimicrobic and antiviral properties. However, all known iodine-containing drugs are characterized as highly toxic substances and therefore in fact are not used in medical practice for parenteral introduction. Both in Armenicum and in the new anti-infective drug molecular iodine adopts such an active form that when introduced orally it minimizes toxic effects in humans.

Armenicum is composed of the $\mathrm{LiI}_{5}-\alpha$-dextrin complex. The AID contains polypeptides along with the $\mathrm{LiI}_{5}-\alpha$-dextrin complex.

A model of the drug active complex of the AID and Armenicum was proposed based on $\mathrm{X}$-ray data for $\mathrm{LiI}_{5}-\alpha$-dextrin complexes and the results of quantum-chemical ab initio $\mathrm{RHF} / 3-21 \mathrm{G}^{* *}$ level calculations [10].

It has been shown that the drug active complex (AC) contains molecular iodine located inside the $a$-dextrin helix and coordinated by lithium halogenides and polypeptide. The electronic structure of $\mathrm{I}_{2}$ in this complex differs from that in complexes with organic ligands or the free $\mathrm{I}_{2}$ form. In the ACs under study the molecular iodine displays acceptor (donor) properties towards polypeptide (lithium halogenides) [10].

In this paper, using the quantum-chemical DFT / B3PW91 and UV spectroscopy data, we have shown that when $\mathrm{LiCl}(\mathrm{I})-\mathrm{I}_{2}-\alpha$-dextrin-

*Corresponding author: Gulnara A Yuldasheva, Scientific Centre for Anti-Infectious Drugs, Kazakhstan, Tel: 8727 379-52-29; E-mail: yuldasheva57@rambler.ru

Received May 20, 2015; Accepted May 22, 2015; Published May 30, 2015

Citation: Yuldasheva GA, Argirova R et al. (2015) A Quantum-Chemical Model of the Inhibition HIV-1 Intergrase Action by lodine Complex Compounds and Lithium Halogenides J AIDS Clin Res 6: 465. doi:10.4172/2155-6113.1000465

Copyright: (C) 2015 Yuldasheva GA, et al. This is an open-access article distributed under the terms of the Creative Commons Attribution License, which permits unrestricted use, distribution, and reproduction in any medium, provided the original author and source are credited. 
peptide complexes ( $\mathrm{LiCl}(\mathrm{I})-\mathrm{I}_{2} \mathrm{DP}$ ) interact with the viral DNA, nucleotides displace peptide and form a complex with molecular iodine and lithium halogenides ( $\mathrm{LiCl}(\mathrm{I})-\mathrm{I}_{2}$ - $\alpha$-dextrin-nucleotide). $\mathrm{LiCl}(\mathrm{I})$ $\mathrm{I}_{2}$-a-dextrin-nucleotide complex inhibits the active catalytic site of integrase inside the PIC.

The effect of antiviral action of $\mathrm{LiCl}(\mathrm{I})-\mathrm{I}_{2}$ - $\alpha$-dextrin-peptide complexes against HIV-1 has been established on a line of lymphoblastoid human cells MT-2. The mechanism of anti-HIV action of $\mathrm{LiCl}(\mathrm{I})-\mathrm{I}_{2}$ - $\alpha$-dextrin-peptide complexes has been suggested.

\section{UV-spectroscopy research of interaction AC with nucleotide triplet AGA}

We have suggested a mechanism of anti-HIV action of Armenicum and $\mathrm{LiCl}(\mathrm{I})-\mathrm{I} 2 \mathrm{DP}$. In the active complex molecular iodine located inside the $\alpha$-dextrin helix and coordinated by lithium halogenides and amide protein component appears to be hard-to-reach for interaction with bioorganic compounds.

Only bioorganic compounds whose donor activity is greater than that of amide can compete with it for producing complexes with $\mathrm{I}_{2}$. The donor activity of nucleotides is greater than that of amides.

Having optimized the geometry of structures in which amide and nucleotide compete with each other for the formation of a complex with $\mathrm{I}_{2}$ we have shown that the purine bases of adenosine and guanosine replace amide and form a complex with molecular iodine and lithium halogenides.

UV spectroscopy is one of the most widely used methods for studying the structure of DNA [11,12]. UV spectra are sensitive to the type of nucleotide base and to the formation of hydrogen or coordination bonds within the DNA. For that reason this method is often used to investigate the interaction of drugs with DNA nucleotides [13-15].

Using UV spectroscopy, we investigated the interaction of $\mathrm{LiCl}(\mathrm{I})-\mathrm{I}_{2}$ DP with the AGA nucleotide triplet.

Figure 1 shows the UV spectra of aqueous solutions of the AGA nucleotide triplet (system a) of the $\mathrm{LiCl}(\mathrm{I})-\mathrm{I} 2 \mathrm{DP}$ (system b) and the aqueous solution of the LiCl-I2-DP complex and the AGA nucleotide triplet (system c).

Comparing the UV spectra of aqueous solutions of systems (a-c) shows that in system (c) the nucleotide triplet is observed to interact with the $\mathrm{LiCl}(\mathrm{I})-\mathrm{I} 2 \mathrm{DP}$ complex: $~ 287 \mathrm{~nm}$ band observed in system (b) in the UV spectrum of system (c) disappears, while the band at $256 \mathrm{~nm}$ observed in system (a), becomes less intense and changes shape.

Using the DFT/B3PW91 method with the basis $6-31 \mathrm{G}^{* *}$ for the atoms of $\mathrm{C}, \mathrm{N}, \mathrm{O}, \mathrm{H}, \mathrm{Li}, \mathrm{Cl}$ and the midi basis for the atom of I with the complete optimization of geometry the structures of molecular iodine complexes with nucleotides adenosine (I) and guanosine (II) and $\mathrm{LiCl}$ (Figure 1) were obtained.

The TD-DFT/B3PW9 method was used to calculate the energies of electronic transitions in complexes I and II (Tables 1 and 2).

The splitting of the experimental band at $\sim 200 \mathrm{~nm}$ can be described by electron transitions $206.51 \mathrm{~nm}, 210.20 \mathrm{~nm}$ and $218.63 \mathrm{~nm}$ in complex I. Transitions between $\pi$-orbitals of $I_{2}$ and $\pi$-orbitals of the nucleotide base contribute to these frequencies. The electronic transition due to the transfer of electron density from $\mathrm{I}_{2}$ to lithium chlorine also contributes to the $210.20 \mathrm{~nm}$ frequency, while the transition between the occupied orbitals of the coordination bond N-I and unoccupied orbitals I contributes to the $218.63 \mathrm{~nm}$ frequency. Complex II also has the $215.09 \mathrm{~nm}$ transition between occupied and unoccupied orbitals $\mathrm{I}_{2}$, which contributes to the band $\sim 200 \mathrm{~nm}$.

Contributing to the $223 \mathrm{~nm}$ band in complex I are the following two transitions: $226.57 \mathrm{~nm}$ and $234.55 \mathrm{~nm}$, which may be referred to transitions between occupied and unoccupied orbitals of the nucleotide base of adenosine and to transitions between occupied and unoccupied orbitals of $\mathrm{I}_{2}$. In complex II contributions to the said band are made by the $233.71 \mathrm{~nm}$ transition that corresponds to the transfer of electron density from the molecular iodine onto $\pi$-orbitals of the nucleotide base of guanosine.

Comparison of the quantum chemical calculations for electronic transitions for the structure modeling the interaction of LiCl-I2-DP with the nucleotide triplet indicates that the DNA nucleotides can displace polypeptide and form stable complexes with molecular iodine and lithium halogenides. In such structures, molecular iodine binds both nucleotide triplet and lithium halogenides.

Thus, the conclusion made only on the basis of quantum-chemical calculations about the possibility of interaction of viral DNA nucleotides with $\mathrm{LiCl}(\mathrm{I})-\mathrm{I}_{2}-\alpha$-dextrin complexes, that are part of drugs [6-10] is confirmed by UV spectroscopy and quantum chemical studies.

\section{The mechanism of inhibition of the catalytic site of HIV- integrase}

The structure of HIV-integrase can be divided into three domains: a short $\mathrm{N}$-terminal domain, a catalytic domain, and a C-terminal domain. A model of the integrase structure in combination with the viral and cellular DNA was proposed in [16]. According to this model, it is the catalytic domain that binds the viral DNA, while all three domains bind the cellular DNA

The structure of the catalytic domain of integrase was determined by X-ray analysis. According to the data obtained, the catalytic domain in a crystal forms a spherical dimer with each monomer, shaped like a hemisphere. Three amino acid residues located close to one another in the tertiary structure of the catalytic domain form two active catalytic sites in each monomer, localized at the opposite end of the dimer. X-ray data clearly show a magnesium ion, coordinated by Asp64 Asp116 and two water molecules [17-18].

In [19] it is assumed that two $\mathrm{Mg}^{2+}$ are involved in the catalytic act, but due to the high conformational mobility of the catalytic fragment they may be bound only when they bind to the viral DNA. Using the method of molecular dynamics it is shown that the interaction with the viral DNA includes the integration of two $\mathrm{Mg}^{2+}$ in a stable binuclear complex, where the amino acid residue Glu152 simultaneously coordinates the two magnesium ions, whereas Asp64 and Asp116 interact with one magnesium ion only.

Recently X-ray diffraction data were obtained for the structure of integrase in combination with the viral DNA [20]. Based on these data, the authors suggest that the act of catalytical cleavage of the phosphoester bond involves two magnesium ions bound by amino acid residue Glu221, and each of the magnesium ions is coordinated by amino acid residues Asp128 and Asp185.

At its ends the viral DNA has direct repeats, consisting of hundreds of base pairs. At a distance of two nucleotides from the 3 -terminus of each DNA chain there is a conservative dinucleotide CA. Integrase as part of the PIC recognizes the nucleotide sequences located at the ends 


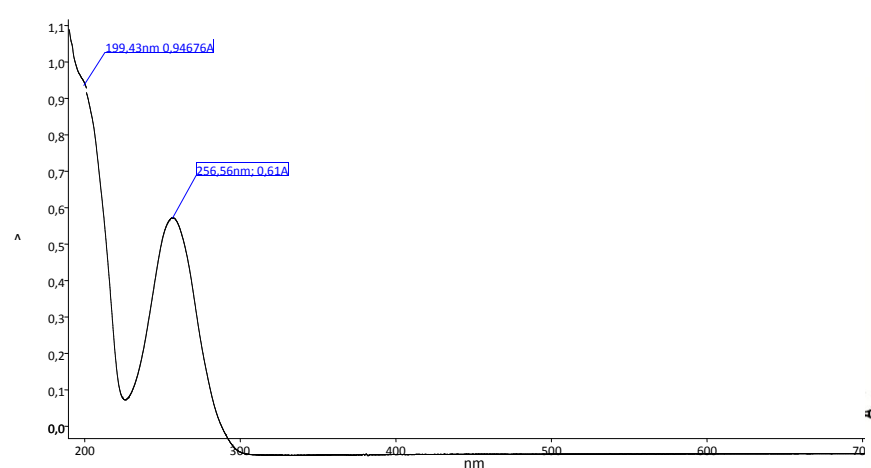

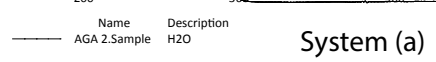

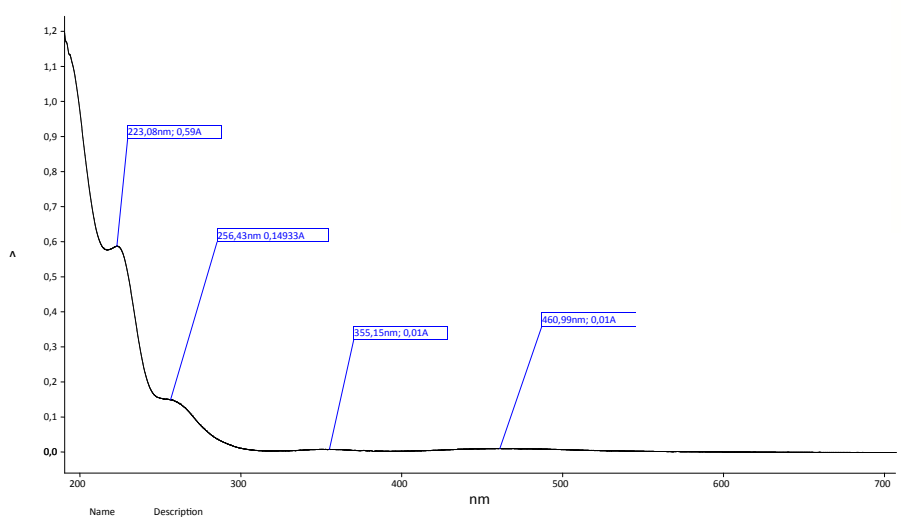

System (c) AGA triplet+ LiCI(I)-I2 DP

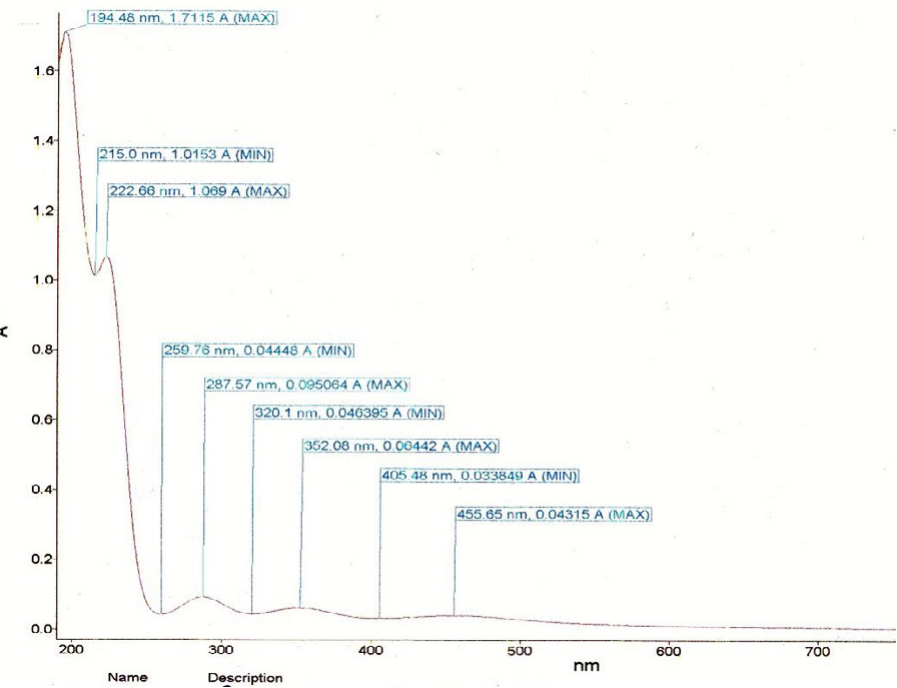

System (b) LiCl(I)-I2 DP

Figure.1: UV-spectrum system (a-c).

\begin{tabular}{|c|c|}
\hline \multirow{3}{*}{$\begin{array}{c}\lambda^{\text {theor. }} \\
206.51\end{array}$} & \\
\hline & ${ }^{\mathrm{I}} \mathrm{A} \rightarrow{ }^{1} \mathrm{~A}\left(\pi\left(\mathrm{I}_{2}\right) \rightarrow \pi\right.$ (nucleot. $\left.)\right)$ \\
\hline & ${ }^{1} \mathrm{~A} \rightarrow{ }^{1} \mathrm{~A}(\pi$ (nucleot $) \rightarrow \pi$ (nucleot $\left.)\right)$ \\
\hline 210.20 & ${ }^{1} \mathrm{~A} \rightarrow{ }^{1} \mathrm{~A}\left(\pi\left(\mathrm{I}_{2}\right) \rightarrow \pi\right.$ (nucleot. $\left.)\right)$ \\
\hline & ${ }^{1} \mathrm{~A} \rightarrow{ }^{1} \mathrm{~A}((\mathrm{Cl}-\mathrm{Li}-\mathrm{I}) \rightarrow \pi(\mathrm{I}))$ \\
\hline 218.63 & ${ }^{1} \mathrm{~A} \rightarrow{ }^{1} \mathrm{~A}(\pi$ (nucleot. $\left.) \rightarrow \pi\left(1_{2}\right)\right)$ \\
\hline 226.57 & $\frac{{ }^{1} \mathrm{~A} \rightarrow{ }^{1} \mathrm{~A}((\mathrm{~N}-\mathrm{I}-\mathrm{I}) \rightarrow \pi(\mathrm{I}))}{{ }^{1} \mathrm{~A} \rightarrow{ }^{1} \mathrm{~A}(\pi(\text { nucleot. }) \rightarrow \pi(\mathrm{I}))}$ \\
\hline 234.55 & ${ }^{1} \mathrm{~A} \rightarrow{ }^{1} \mathrm{~A}\left(\pi\left(\mathrm{I}_{2}\right) \rightarrow \pi\left(\mathrm{I}_{2}\right)\right)$ \\
\hline 244.34 & $\begin{array}{l}\left.{ }^{1} \mathrm{~A} \rightarrow{ }^{1} \mathrm{~A}(\pi \text { (nucleot. }) \rightarrow \pi\left(\mathrm{I},{ }^{2}\right)\right) \\
\left.{ }^{1} \mathrm{~A} \rightarrow{ }^{1} \mathrm{~A}(\pi \text { (nucleot. }) \rightarrow \pi(\text { nucleot. })\right)\end{array}$ \\
\hline
\end{tabular}

Table 1: Theoretical wavelengths $(\lambda, \mathrm{nm})$ of electronic transitions in complex I.

of the viral DNA, binds to them and subsequently catalyzes the reaction of endonuclease cleavage of the viral DNA, which results in the removal of GT dinucleotide from the 3 'end of each strand. The rupture of a phosphoester link in the phosphate group of the viral DNA is catalyzed by the active catalytic center of integrase.

In [21] the mechanism of the catalytic cleavage of the phosphoester bond was considered in the framework of molecular dynamics and DFT methods of quantum chemistry. The study begins with the construction of an initial transient state in which two magnesium ions coordinate the oxygen atom of the phosphoester group.

The authors do not consider the stable complex which is formed

\begin{tabular}{|c|l|}
\hline$\lambda^{\text {theor. }}$ & \\
\hline 215.09 & ${ }^{1} \mathrm{~A} \rightarrow{ }^{1} \mathrm{~A}\left(\pi\left(\mathrm{I}_{2}\right) \rightarrow \pi\left(\mathrm{I}_{2}\right)\right)$ \\
\hline 233.71 & ${ }^{1} \mathrm{~A} \rightarrow{ }^{1} \mathrm{~A}\left(\pi\left(\mathrm{I}_{2}\right) \rightarrow \pi(\right.$ nucleot. $\left.)\right)$ \\
\hline 244.34 & ${ }^{1} \mathrm{~A} \rightarrow{ }^{1} \mathrm{~A}\left(\pi\left(\mathrm{I}_{2}\right) \rightarrow \pi\left(\mathrm{I}_{2}\right)\right)$ \\
\hline
\end{tabular}

Table 2: Theoretical wavelengths $(\lambda, \mathrm{nm})$ of electronic transitions in complex II.

when the active catalytic site of the integrase interacts with the phosphate group of the viral DNA. However, this information is important when investigating the mechanisms of inhibition of an active integrase.

For the inhibition process against the activity of integrase to become possible, it is necessary that the binding energy of the drug in relation to the active site of integrase was comparable to or greater than its binding energy in relation to the phosphate group of the viral DNA.

In our calculations the structure of the binuclear active catalytic site of the integrase is represented by two magnesium ions bound by $\mathrm{COOCH} 3$ group and each magnesium ion is coordinated by $\mathrm{COOCH}_{3}$ group, while one of the ions is also coordinated by a water molecule.

In the calculated structures hydrocarbon and amide fragments of amino acid residues Asp64, Asp116, and Glu152 are replaced by a methyl group. This simplification of the structure of the amino acid residues is likely to be justified by the fact that the amide moiety is 
separated from the carboxyl group by a number of methyl groups and therefore does not affect their donor activity.

In the structure of DNA the phosphate group is ionized at $\mathrm{pH} 7.8$, with a charge of -1 . However, the metal ions (e.g. $\mathrm{Na}+, \mathrm{K}+$ ) present in the internuclear environment are complexed with the phosphate group and neutralize the negative charge.

In [22] by means of DFT-D using the potential BLYP-D it is shown that sodium ions as counterions make a significant contribution to the stability of the DNA double helix, because they reduce electrostatic repulsion of the phosphate groups and enhance the $\pi-\pi$ stacking interaction of Watson -Krikovskih pairs through the hydrophobic effect.

We considered two cases of neutralization of the charge of phosphate group by $\mathrm{Na}^{+}$or $\mathrm{H}^{+}$, taking into consideration that ionization of the phosphate group is reversible. After ionization two oxygen atoms of the phosphate group become identical, and for that reason $\mathrm{Na}^{+}$or $\mathrm{H}^{+}$, co-ordinates these two atoms.

Calculations have shown that in the most stable structures two magnesium ions displace $\mathrm{Na}^{+}$or $\mathrm{H}^{+}$to form coordination bonds with two oxygen atoms of the phosphate group. $\mathrm{H}^{+}$is displaced from the coordination sphere of the phosphate group to form a covalent bond with one of the oxygen atoms of the carboxy group and forms a hydrogen bond with an oxygen atom of the other carboxy group. However, the displaced $\mathrm{Na}^{+}$forms coordinate bonds with two oxygen atoms of the two carboxyl groups and with one of the oxygen atoms of the phosphate group

Assuming that the complex $\mathrm{LiCl}(\mathrm{I})-\mathrm{I}_{2}-\alpha$-dextrin- nucleotide (adenosine, guanosine) may prevent the formation of a binuclear active catalytic site, we have considered two variants of interaction of magnesium ions with $\mathrm{LiCl}(\mathrm{I})-\mathrm{I}_{2}-\alpha$-dextrin- nucleotide (adenosine, guanosine)) complexes. In one case, the magnesium ion is coordinated by $\mathrm{COOCH}_{3}$ group and a water molecule. In another case, the magnesium ion is coordinated by two $\mathrm{COOCH}_{3}$ groups. In nucleoprotein complexes IVa,b-VIIa,b $a$-dextrin is replaced by a molecule of ethanol.

Figure 2 shows the binding energy of the active catalytic site of the integrase with the phosphate group (structures IIIa-b) and with complexes $\mathrm{LiCl}(\mathrm{I})-\mathrm{I}_{2}-\alpha$-dextrin- nucleotide (adenosine, guanosine) (structure IVa, b-VIIa, b)

The binding energy $\Delta \mathrm{E}_{1}, \Delta \mathrm{E}_{2}, \Delta \mathrm{E}_{3}$ was calculated as follows below:

$\Delta \mathrm{E}_{1}=\mathrm{E}^{\text {tot. }}(\mathrm{IIIa})-\mathrm{E}^{\text {tot. }}\left(\left(\mathrm{CH}_{3}\right)_{2} \mathrm{PO}_{4}^{--}-\mathrm{Na}^{+}\right)-\mathrm{E}^{\text {tot. }}\left(\mathrm{Mg}^{2+}\left(\mathrm{COOCH}_{3}\right)_{2}^{-}\right)-\mathrm{E}^{\text {tot }}$ $\left(\mathrm{H}_{2} \mathrm{OMg}^{2+}\left(\mathrm{COOCH}_{3}\right)^{-}\right)$.

$\Delta \mathrm{E}_{2}=\mathrm{E}^{\mathrm{tot}}(\mathrm{IIIb})-\mathrm{E}^{\mathrm{tot}}\left(\left(\mathrm{CH}_{3}\right)_{2} \mathrm{PO}_{4}^{-}--\mathrm{H}^{+}\right)-\mathrm{E}^{\mathrm{tot}}\left(\mathrm{Mg}^{2+}\left(\mathrm{COOCH}_{3}\right)_{2}^{-}\right)-\mathrm{E}^{\mathrm{tot}}$ $\left(\mathrm{H}_{2} \mathrm{OMg}^{2+}\left(\mathrm{COOCH}_{3}\right)^{-}\right)$.

$$
\Delta \mathrm{E}_{3}=\Delta \mathrm{E}_{4}+\Delta \mathrm{E}_{5}
$$

$\Delta \mathrm{E}_{4}=\mathrm{E}(\mathrm{IVa}, \mathrm{b}$ or $\mathrm{VIa}, \mathrm{b})-\mathrm{E}\left(\mathrm{LiCl}(\mathrm{I})-\mathrm{I}_{2}\right.$-'-dextrin- $^{-}$ nucleotide(adenosine, guanosine))-E( $\left(\mathrm{Mg}^{2+}\left(\mathrm{COOCH}_{3}\right)_{2}^{-}\right)$

$\Delta \mathrm{E}_{5}=\mathrm{E}\left(\mathrm{Va}, \mathrm{b}\right.$ or VIIa,b) - $\mathrm{E}\left(\mathrm{LiCl}(\mathrm{I})-\mathrm{I}_{2}\right.$-'-dextrin- $^{-}$ nucleotide(adenosine, guanosine $)$ )- $\mathrm{E}\left(\mathrm{H}_{2} \mathrm{OMg}^{2+}\left(\mathrm{COOCH}_{3}\right)^{-}\right)$.

instead $\quad \Delta \mathrm{E}_{3}=\mathrm{E}^{\text {tot. }}(\mathrm{IVa}, \mathrm{b}-\mathrm{VII}, \mathrm{b}) \quad-\mathrm{E}^{\text {tot. }}\left(\mathrm{LiCl}(\mathrm{I})-\mathrm{I}_{2}\right.$-'-dextrin- $^{-}$ nucleotide(adenosine, guanosine $)$ - $\mathrm{E}^{\text {tot. }}\left(\mathrm{Mg}^{2+}\left(\mathrm{COOCH}_{3}\right)_{2}^{-}\right)-\mathrm{E}^{\text {tot }}$ $\cdot\left(\mathrm{H}_{2} \mathrm{OMg}^{2+}\left(\mathrm{COOCH}_{3}\right)^{-}\right)$. Our calculations show that in structures Va,bVIIa,b the carboxy group replaces ion $\mathrm{Cl}^{-}\left(\mathrm{I}^{-}\right)$in lithium halogenide, and forms a binuclear complex with $\mathrm{Li}^{+}$and $\mathrm{Mg}^{2+}$, while in structures IVa,b-VIa,b two carboxy groups bind $\mathrm{Li}^{+}$and $\mathrm{Mg}^{2+}$ into the binuclear
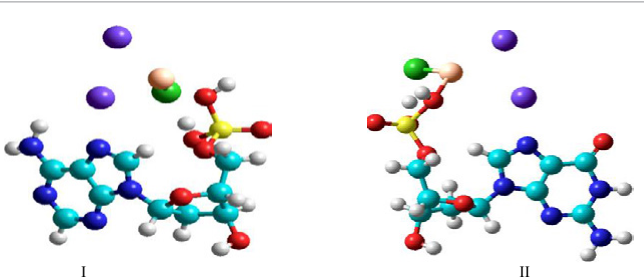

Figure 2: Complexes of molecular iodine with adenosine (I), guanosine (II) and and lithium chlorine. In the figure: blue balls-carbon atoms, dark blue balls - nitrogen atoms, red balls - oxygen atoms, violet balls - iodine atoms, orange balls - lithium atoms, green balls -chlorine atoms, yellow balls phosphor atoms.

In the figure 3: blue balls-carbon atoms, dark blue balls - nitrogen atoms, red balls - oxygen atoms, violet balls - iodine atoms, green balls - magnesium atoms, orange balls-lithium atoms, yellow balls - phosphor atoms, black ballhalogen atom.

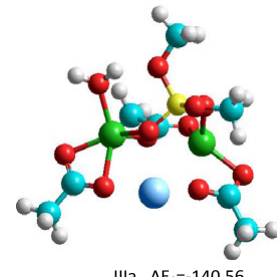

IIIa $\Delta \mathrm{E}_{1}=-140,56$

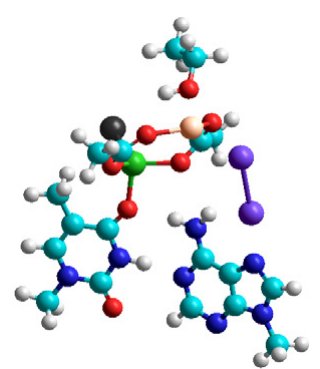

IVa $(\mathrm{X}=\mathrm{Cl})$

$\operatorname{IVb}(X=1)$

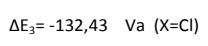

$\Delta \mathrm{E}_{3}=-128,49 \quad \mathrm{Vb} \quad(\mathrm{X}=\mathrm{I})$

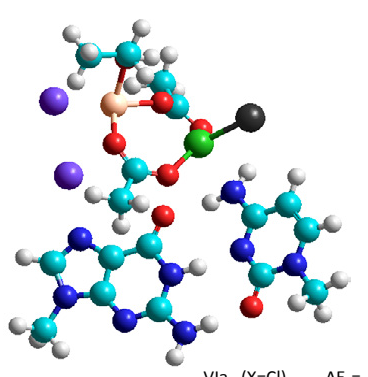

Vla $(\mathrm{X}=\mathrm{Cl}) \quad \Delta \mathrm{E}_{3}=-88,99$

$\operatorname{VIb}(X=1) \quad \Delta \mathrm{E}_{3}=-84,59$

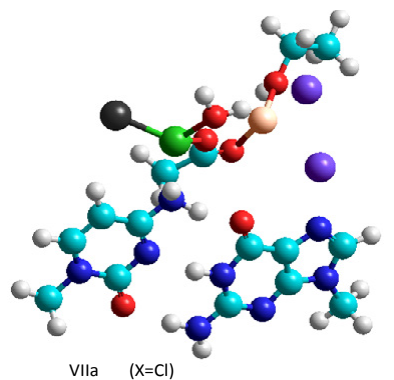

VIIb $\quad(X=1)$

Figure 3: shows the binding energy of the active catalytic site of the integrase with the phosphate group (structures IIla-b) and with complexes $\mathrm{LiCl}(\mathrm{I})-\mathrm{I}_{2}-\alpha-$ dextrin- nucleotide (adenosine, guanosine) (structure IVa, b-VIla, b).

complex. Also $\mathrm{Mg}^{2+}$ forms a coordination bond with $\mathrm{Cl}^{-}$and the oxygen atom of the carbonyl group of thymine in structures IVa, b-Va, b or the nitrogen of the amino group of cytosine in structures VIa,b-VIIa,b.

As can be seen in Figure 3 it is only $\mathrm{LiCl}(\mathrm{I})-\mathrm{I}_{2}-\alpha$-dextrin-adenosine complexes that can compete with the phosphate group for binding the catalytic active center, because in this case $\Delta \mathrm{E}_{3}$ lies between $\Delta \mathrm{E}_{1}$ and 
$\Delta \mathrm{E}_{2}$.

The great difference in stability of IVa,b-Va,b and VIa,b-VIIa,b structures is due to low donor activity of the nitrogen atom in the amino group of cytosine as compared to that of the oxygen atom of the carbonyl group of thymine.

Thus, $\mathrm{LiCl}(\mathrm{I})-\mathrm{I}_{2}-\alpha$-dextrin complexes, that are part of the active centre of drugs [6-10] inhibit the catalytic activity of the active catalytic site of integrase within the PIC. Lithium ion becomes a trap for the $\mathrm{Mg}^{2+}\left(\mathrm{COOCH}_{3}\right)_{2}^{-}$and $\mathrm{H}_{2} \mathrm{OMg}\left(\mathrm{COOCH}_{3}\right)^{-}$complexes, that form the structure of the active catalytic site of integrase. In the presence of $\mathrm{LiCl}(\mathrm{I})-\mathrm{I}_{2}-\mathrm{a}$-dextrin-complexes magnesium ions are coordinated by the carbonyl oxygen atom of thymine rather than by the atoms of oxygen in the phosphate group. The conditions that ensure the occurrence of catalytic cleavage of the phosphoester bond are disturbed.

In IVa,b-Va,b nucleoprotein complexes the spatial structure of Watson - Crick pairs gets deformed, the planes of adenosine and thymine molecule are located at an angle of $\sim 15^{\circ}$, while the distance between oxygen and hydrogen atoms linked by intermolecular hydrogen bond becomes equal to $\sim 2,03 \AA$ (hydrogen bond $\mathrm{O}$--- $\mathrm{H}$ breaks.), while that for hydrogen and nitrogen atoms becomes equal to $\sim 1,80 \AA$.

\section{Experimental Research}

\section{Materials and methods}

Tested compound - AID [9]: The compounds under study were first dissolved in absolute ethanol to 1:1000 dilution and after that further diluted in cell growth medium without fetal serum. All solutions were prepared ex tempore.

Cell line and virus: MT-2 cell line used routinely as a target for study of acute HIV-1 infection. H9/HTLV III B cell line (a gift from Dr. R. Gallo (Natl. Inst. Of Health, USA) was chronically infected and produced HIV-1 $1_{\text {LAI }}$ strain. As a source of HIV1 , the supernatant of H9/HTLV III B cell line was used. The supernatants were collected and centrifuged to remove the cells, and virus stocks were prepared with known p24 antigen content, RT activity and infectivity.

MT-2 cells were infected with HIV-1 (multiplicity of infection $\geq 1)$ in suspension $\left(37^{\circ} \mathrm{C} / 5 \% \mathrm{CO}_{2}\right)$ and then grown paralelly with uninfected cells for 72 hours.

\section{Anti-HIV assays}

The infectivity was measured on MT-2 cells by microtiter infection assay using MTT test. Briefly, the experimental procedure under conditions of acute infection was performed in 96-well microplates previously treated for an hour with $50 \mu \mathrm{g} / \mathrm{ml}$ poly-L-lysine (PLL) in volume $100 \mu \mathrm{l}$ in the following sequence:

- $\quad 1 / 100 \mu \mathrm{l} \mathrm{MT-2}$ cells $\left(5-7 \times 10^{4}\right.$ cells) earlier infected with HIV-1 ( 1 hour, $37^{\circ} \mathrm{C}, 5 \% \mathrm{CO}_{2}$ ) - i.e. virus control or uninfected - i.e. cell control;

- $\quad 2 / 50 \mu \mathrm{l}$ sample of substance to be tested starting from $4 \mathrm{x}$ MNC (because this volume is $1 / 4$ of the whole volume in the well) and 2 or more 10 -fold dilutions in growth medium;

- $\quad 3 / 50 \mu l$ growth medium.

So, each plate contained 6 - 8 cell controls (no virus, no substance) for all experiments, rows of $6-8$ viral controls (plus virus, no substance) and rows of $6-8$ experimental wells (plus virus and plus different dilutions of the substance). The values of optical density at $540 \mathrm{~nm}$ (A540) were averaged for each row. The mean values of experimental and control rows were compared and the percentage of cells protected under the appropriate concentration of the substance studied was plotted against the concentration of the substance.

The cells were incubated for 72 hours. The tissue culture fluid (supernatants) from each well was collected and removed in appropriate (mirror-like) non-sterile 96-well plate and stored in $4^{\circ} \mathrm{C}$ until the results of A540 reading were ready.

\section{Detection of Reverse Transcriptase (RT) activity}

Endogenous RT activity of supernatants of HIV-1 infected MT-2 cells treated/untreated with the substances was tested by HS-Lenti KitRT assay (Cavidi, Sweden). The kit contained recombinant RT (rRT) as a standard which made possible the quantitation of the RT in the samples. The method is non-radioactive and colorimetrically detects the product of reverse transcription at $405 \mathrm{~nm}$ (A405). The activity was expressed as \% from the viral control.

Detection of the effect of the substances on recombinant Reverse Transcriptase (rRT) activity

A possible direct action of the substances having shown anti-HIV-1 effect on MT-2 infected cells measured by RT assay in supernatants was further studied using rRT standard provided by Cavidi kit. The reaction mixture for the assay was prepared with the active substance (in the appropriare dilutions) or without them and the reverse transcription was carried out with the standard rRT. A405 was then measured for the samples where the active substance has been added in different solutions and compared to that of the control (where only incubation mixture without any substance was added). The rRT activity was expressed as $\%$ compared to the control positive reaction.

\section{Results and Discussion}

Each experiment has been done in triplicates; each run was carried out with $6-8$ parallels. Only parallels differing in less than $10 \%$ in A540 were collected for further RT assay.

${ }^{1} \mathrm{MNC}$ - was evaluated as maximal nontoxic concentration of the substance which altered neither the morphology nor the survival rate of MT-2 cells.

${ }^{2}$ mean values of six to eight paralells per experiment with standard deviation $\leq 10 \%$ in MTT test; each experiment run in triplicate. \% cell survival at different inhibitor concentrations.

${ }^{3}$ from duplicate experiments. RT activity is the ratio between the RT in supernatants of inhibitor-treated HIV-1 infected MT-2 cells and that in untreated HIV-1 infected MT-2 cells (virus control, 100\%). \% inhibition is $100 \%$ - \% RT activity (not shown in the Table 3).

${ }^{4}$ from duplicate experiments. rRT activity was measured in incubation mixture without addition of inhibitor (100\%) and compared to the same activity in incubation mixture where inhibitor was added in appropriate concentration. \% inhibition is $100 \%$ - rRT activity (not shown).

\section{NA - not applicable}

Table 3 shows a remarkable inhibition of RT activity in supernatants of HIV-1 infected MT-2 cells treated with AID substances in 2x dilutions. At the same time no inhibition is seen when the compounds are added directly to the incubation mixture to allow reverse transcription with a recombinant RT - i.e. the inhibition observed in tissue culture is not due to direct action on the RT enzyme. 


\begin{tabular}{|c|c|c|c|c|}
\hline Substance & $\begin{array}{l}\text { Compound } \\
\text { Concentration } \\
\text { (dilution) }\end{array}$ & $\begin{array}{c}\text { Infection } \\
\text { assay } \\
\text { MTT-A540 } \\
(\% \text { cell } \\
\left.\text { survival }{ }^{2}\right)\end{array}$ & $\begin{array}{l}\text { Supernatant } \\
\text { RT activity } \\
\text { A405 } \text { (Control) } \\
\% \text { inhibition }\end{array}$ & $\begin{array}{c}\text { Incub. } \\
\text { mixture } \\
\text { rRT activity } \\
\text { A4054 } \\
\text { (Control) } \\
\% \\
\text { inhibition }\end{array}$ \\
\hline \multirow[t]{3}{*}{ AID } & 1:5000 (MNC') & $\begin{array}{l}1,840 \\
(92,9)\end{array}$ & $\begin{array}{c}0,713(2,703) \\
73,7\end{array}$ & $\begin{array}{c}2,096 \\
(2,258) \\
0\end{array}$ \\
\hline & 1:10000 & $\begin{array}{l}1,902 \\
(96,0)\end{array}$ & $\begin{array}{c}0,744(2,703) \\
72,5\end{array}$ & $\begin{array}{c}2,179 \\
(2,258) \\
0\end{array}$ \\
\hline & 1:20000 & $\begin{array}{l}1,946 \\
(98,2)\end{array}$ & $\begin{array}{c}0,807(2,703) \\
70,2\end{array}$ & $\begin{array}{c}2,165 \\
(2,258) \\
0\end{array}$ \\
\hline Cell control & 0 & $\begin{array}{l}1,980 \\
(100)\end{array}$ & $\begin{array}{c}0,231 \\
0\end{array}$ & NA \\
\hline Virus control & 0 & 1,315 & $\begin{array}{c}2,703 \\
100\end{array}$ & NA \\
\hline
\end{tabular}

Table 3: AID inhibition of HIV-1 replication in MT-2 cells expressed in MTT infection assay and by RT and rRT activity.

These observations mean that both compound $\mathrm{LiCl}(\mathrm{I})-\mathrm{I} 2 \mathrm{DP}$ inhibit HIV-1 replication. This is clearly demonstrated by the inhibition of RT activity in the supernatants of MT-2 infected cells. The target and mechanism of action of compound should be further elucidated by looking for another viral targets - i.e. integrase and/or protease .

\section{Conclusion}

The water-nucleotide AGA triplet - $\mathrm{LiCl}(\mathrm{I})-\mathrm{I}_{2}-\boldsymbol{\alpha}$-dextrin-peptide system was investigated using UV spectroscopy. The good agreement between the experimental UV-frequencies of the system with the theoretical frequencies for $\mathrm{LiCl}(\mathrm{I})-\mathrm{I}_{2}-\alpha$-dextrin-nucleotide complexes indicates that when interacting with $\mathrm{LiCl}(\mathrm{I})-\mathrm{I}_{2}-\alpha$-dextrin complexes AGA triplet nucleotides displace peptide and form a new complex with iodine and lithium halides.

Using the quantum-chemical DFT is was shown that the $\mathrm{LiCl}(\mathrm{I})$ $\mathrm{I}_{2}$ - $\alpha$-dextrin-nucleotide complexes inhibit the activity of the catalytic site of integrase inside the PIC. They disrupt the conditions ensuring the occurrence of catalytical cleavage of the phosphoester bond in the phosphate group of the viral DNA by the active catalytic site of integrase. They form a nucleoprotein complex consisting of the nucleotides of the viral DNA, $\mathrm{LiCl}(\mathrm{I})-\mathrm{I}_{2}-\alpha$-dextrin complexes and active components of the catalytic site of integrase. In these complexes magnesium ions are coordinated by the carbonyl oxygen atom of thymine rather than by the oxygen atoms of the phosphate group.

The effect of antiviral action of $\mathrm{LiCl}(\mathrm{I})-\mathrm{I}_{2}$ - $\alpha$-dextrin-peptide complexes against HIV-1 has been established on a line of lymphoblastoid human cells MT-2. The mechanism of anti-HIV action of $\mathrm{LiCl}(\mathrm{I})-\mathrm{I}_{2}$-a-dextrin-peptide complexes has been suggested.

\section{Reference}

1. Sen S, Mathur AG, Gupta RM, Kapila K, Chopra GS (2008) Investigational antiretroviral drugs. Recent Pat Antiinfect Drug Discov 3: 199-205.

2. Delelis O, Carayon K, Saïb A, Deprez E, Mouscadet JF (2008) Integrase and integration: biochemical activities of HIV-1 integrase. Retrovirology 5: 114

3. Ciuffi A (2008) Mechanisms governing lentivirus integration site selection. Curr Gene Ther 8: 419-429.

4. Farnet CM, Haseltine WA (1990) Integration of human immunodeficiency virus type 1 DNA in vitro. Proc Natl Acad Sci U S A 87: 4164-4168.

5. Farnet CM, Wang B, Lipford JR, Bushman FD (1996) Differential Inhibition of HIV -1 Preintegration Complexes and Purified Integrase Protein by Small Molecules. Proc Natl Acad Sci USA 93: 9742-9747.

6. Patent Pub.No. WO/2001/078751 International Application No.: PCT/ AM2000/000002, International Filling Date 24.11.2000.

7. Davtyan TK, Mkhitaryan LM, Gabrielyan ES (2009) Design of iodine-lithiumalpha-dextrin liquid crystal with potent antimicrobial and anti-inflammatory properties. Curr Pharm Des 15: 1172-1186.

8. Mkhitaryan LM, Davtyan TK, Gabrielyan ES, Gevorkyan LA (2007) Anti-HIV and Anti-inflammatory Action of lodine-Lithium- $\alpha$-Dextrin is Accompanied by the Improved Quality of Life in AIDS Patients. Int J of Biotechnology 9: 301-317.

9. Patent KZ (A) №15116, 15.12.2004, bull 12.

10. Yuldasheva GA, Zhidomirov GM, Ilin AI (2012) Effect of organic ligands with conjugated İ€-bonds on the structure of iodine-Ît-dextrin complexes. Biotechnol Appl Biochem 59: 29-34.

11. Adil Wani, Shaheena Mushtaq, Haseeb Ahsan, Rizwan Ahmad (2012) Biochemical Studies of In Vitro Glycation of Human DNA. Asian Journal of Biomedical and Pharmaceutical Sciences 2: 23-27.

12. AL- Rubaee Eaman AS (2014) IR AND UV Spectroscopy Studies of DNA Stability. IJSN 5: 22-27.

13. Rosu F, Gabelica V, De Pauw E, Antoine R, Broyer M, et al. (2012) UV spectroscopy of DNA duplex and quadruplex structures in the gas phase. $J$ Phys Chem A 116: 5383-5391.

14. Fouzia Perveen, Rumana Qureshi, Farzana Latif Ansari, Saima Kalsoom, Safeer Ahmed (2011) Investigations of drug-DNA interactions using molecular docking, cyclic voltammetry and UV-Vis spectroscopy. Journal of Molecular Structure 1004: 67-73.

15. Muhammad Sirajuddin, Saqib Ali, Amin Badshah (2013) Drug-DNA interactions and their study by UV-Visible, fluorescence spectroscopies and cyclic voltammetry. J Photochemistry Photobiology B 124: 1-19.

16. Podtelezhnikov AA, Gao K, Bushman FD, McCammon JA (2003) Modeling HIV1 integrase complexes based on their hydrodynamic properties. Biopolymers 68: $110-120$.

17. Dyda F, Hickman AB, Jenkins TM, Engelman A, Craigie R, et al. (1994) Crystal Structure of Catalytic Domain of HIV-1 Integrase: Similarity to Other Polynucleotidyl Transferases. Science 266: 1981-1986.

18. Goldgur Y, Dyda F, Hickman AB, Jenkins TM, Craigie R, et al. (1998) Three new structures of the core domain of HIV-1 integrase: an active site that binds magnesium. Proc Natl Acad Sci U S A 95: 9150-9154.

19. Chen X, Tsiang M, Yu F, Hung M, Jones GS, et al. (2008) Modeling, Analysis, and Validation of a Novel HIV Integrase Structure Provide Insights into the Binding Modes of Potent Integrase Inhibitors. J Mol Biol 380: 504-519.

20. Hare S, Gupta SS, Valkov E, Engelman A, Cherepanov P (2010) Retroviral Intasome assembly and inhibition of DNA strand transfer. Nuture 464: 231-236.

21. Ribeiro AJ, Ramos MJ, Fernandes PA (2012) The catalytic mechanism of HIV-1 integrase for DNA 3'-end processing established by QM/MM calculations. J Am Chem Soc 134: 13436-13447.

22. Barone G, Fonseca Guerra C, Bickelhaupt FM (2013) B-DNA Structure and Stability as Function of Nucleic Acid Composition: Dispersion-Corrected DFT Study of Dinucleoside Monophosphate Single and Double Strands. ChemistryOpen 2: 186-193. 